\title{
ACTIVATION OF GLUCOSE-6-PHOSPHATE DEHYDROGENASE OF ENZYME-DEFICIENT SUBJECTS. II. PROPERTIES OF THE ACTIVATOR AND THE ACTIVATION REACTION *
}

\author{
BY BRACHA RAMOT, ISRAEL ASHKENAZI, ABRAHAM RIMON, \\ AVINOAM ADAM AND CHAIM SHEBA \\ (From the Tel-Hashomer Government Hospital and Marcus Memorial Blood Institute- \\ Magen David Adom in Israel, Jaffa, Israel)
}

(Submitted for publication June 8, 1960; accepted November 10, 1960)

The primary metabolic defect in subjects susceptible to hemolysis by various drugs and fava beans is considered to be the low glucose-6-phosphate dehydrogenase (G6PD) activity in their red cells $(1,2)$. Such diminished enzymatic activity could be the end result of qualitative or quantitative changes in the enzyme as well as enzyme inhibition or lack of enzyme activation. However, studies on the properties of erythrocyte G6PD in such subjects and in normal subjects revealed no qualitative difference between them $(3,4)$.

In a previous communication we demonstrated the presence of an activator of G6PD in normal erythrocyte stroma which increased the G6PD activity in the "sensitive" ${ }^{1}$ hemolysate (5). This activator was found to be absent in the stroma of "sensitive" erythrocytes. Our recent finding that G6PD activity is also present in red cell stroma made it necessary to reinvestigate the validity of the G6PD activator.

\section{METHODS}

Bank blood collected in an ACD ${ }^{2}$ solution and stored for about 2 weeks was used for the preparation of stroma. The red cells were washed three times in 0.85 per cent $\mathrm{NaCl}$ solution and the red cell stroma was prepared by gradual hemolysis as follows: to 1 vol of packed erythrocytes 9 vol of cold distilled water was added by drops, using a magnetic stirrer. The stroma was obtained by centrifugation at $28,000 \mathrm{G}$ for 30 minutes. The stroma was suspended in 10 vol of 0.15 per cent $\mathrm{NaCl}$ solution and centrifuged for 5 minutes. This procedure was

* This work was supported by grants from the Rockefeller Foundation and the United States Public Health Service (A-2740).

1 Hemolysates and stroma obtained from erythrocytes which exhibit a very low G6PD activity will be referred to as "sensitive."

2 Acid citrate dextrose, Formula B. National Institutes of Health, USA. repeated about ten times until the supernatant was almost colorless and contained no G6PD activity. The packed stroma was diluted with an equal volume of 0.85 per cent $\mathrm{NaCl}$ solution. One $\mathrm{ml}$ of such a stroma suspension contains about $30 \mathrm{mg}$ dry weight. The hemolysates were prepared from fresh blood taken in heparin or ACD solution. The red cells were washed three times in 0.85 per cent $\mathrm{NaCl}$ solution. The cells were lysed by the addition of $4 \mathrm{vol}$ of water to 1 vol of packed red cells. The stroma was removed from the hemolysates by centrifugation at $28,000 \mathrm{G}$ and the supernatants used.

Glucose-6-phosphate dehydrogenase and 6-phosphogluconic dehydrogenase (6PGD) were assayed by a slight modification of the method of Kornberg and Horecker (6) and Horecker and Smyrniotis, respectively (7), as used in this laboratory (8).

The presence of G6PD and 6PGD in stroma suspension was demonstrated by the method of Motulsky and Campbell (9), which is based on dye discoloration. The reaction mixture contained $0.4 \mathrm{ml}$ stroma suspension added to $2 \mathrm{ml}$ water. To that were added $0.4 \mathrm{ml}$ of $0.25 \mathrm{M}$ Tris buffer, $\mathrm{pH} 7.5 ; 0.5 \mathrm{ml}$ of $5 \times 10^{-3} \mathrm{M}$ glucose-6-phosphate or 6-phosphogluconate; $0.1 \mathrm{mg}$ TPN ; and $0.5 \mathrm{ml}$ of 0.03 per cent brilliant cresyl blue. After mixing, the reaction mixture was covered with $1 \mathrm{ml}$ mineral oil and incubated at $37^{\circ} \mathrm{C}$. The rate of the dye reduction is directly related to TPNH formation. The latter is formed when either the glucose-6-phosphate or 6-phosphogluconate is oxidized. This is a semiquantitative screening method used to distinguish normal from G6PD-deficient subjects.

Partial purification of G6PD was performed by precipitating the enzyme from a normal or "sensitive" hemolysate with 20 per cent ethanol. The precipitate was suspended in $0.2 \mathrm{M}$ Tris buffer, $\mathrm{pH}$ 8.0. The enzyme went into solution and the residue was discarded. By the addition of ammonium sulfate, up to a concentration of 40 per cent ( $w t / v o l)$ to the solution, the enzyme was reprecipitated. By this method a 20 -fold purification based on the total protein content of the hemolysate was achieved. The yield of enzyme obtained was about 60 per cent.

\section{RESULTS}

Properties of the activation reaction. The effect of red cell stroma on G6PD activity of red cell hemolysate is summarized in Table I. It is obvious 
TABLE I

The effect of red cell stroma on G6PD activity in hemolysates

\begin{tabular}{|c|c|c|c|}
\hline \multirow{2}{*}{$\begin{array}{l}\text { No. of } \\
\text { expts. }\end{array}$} & \multicolumn{2}{|c|}{ Reaction mixture* } & \multirow{2}{*}{$\underset{\text { activity }}{\text { G6PD }}$} \\
\hline & Stroma & Hemolysate & \\
\hline $\begin{array}{l}14 \\
55\end{array}$ & & $\begin{array}{l}\text { Normal } \\
\text { "Sensitive" }\end{array}$ & $\begin{array}{r}14.3 \pm 7.9 \\
1.6 \pm 1.1\end{array}$ \\
\hline 14 & "Sensitive" & Normal & $14.2 \pm 7.7$ \\
\hline 7 & "Sensitive" & "Sensitive" & $1.7 \pm 1.7$ \\
\hline 9 & Normal & Normal & $15.1 \pm 8.9$ \\
\hline 55 & Normal & "Sensitive" & $7.5 \pm 6.6$ \\
\hline
\end{tabular}

* The reaction mixture contained $1 \mathrm{ml}$ of hemolysate added to $1 \mathrm{ml}$ of stromal suspension when indicated. After 15 minutes' incubation the reaction mixture was spun down at $28,000 \mathrm{G}$ for 10 minutes and the supernatant used for the enzymatic assay.

$\dagger$ In $\Delta$ A per minute per gram hemoglobin; mean activity \pm standard deviation.

that normal red cell stroma has significantly increased the enzymatic activity of sensitive hemolysates (sometimes even to normal levels). No such effect was observed with sensitive stroma. When sensitive and normal stroma were mixed in different proportions the activating capacity of normal stroma was not affected.

The activation reaction progressed with time (Figure 1). It can be seen that under these experimental conditions the activation reached its maximum at about 10 minutes. This reaction was found to be $\mathrm{pH}$-dependent, being optimal at about pH 7.2 (Figure 2), and temperature-dependent (Figure 3).

The effect of metal ions was tested on the activation reaction and on G6PD activity. Figure 4

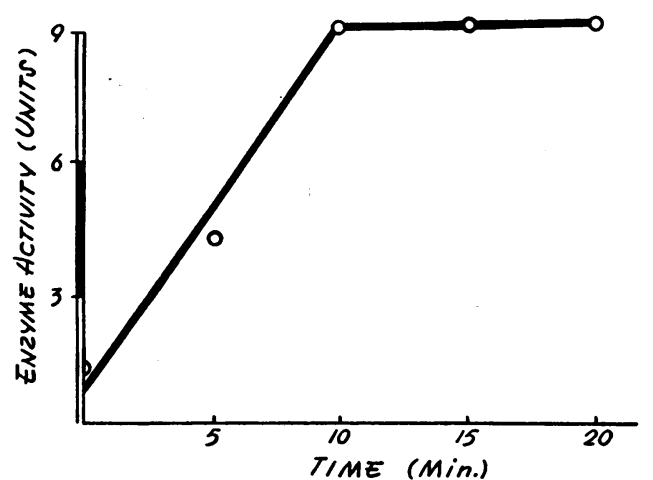

Fig. 1. The effect of time on the activation ReACtIoN. The incubation mixture consisted of $1 \mathrm{ml}$ of "sensitive" hemolysate and $1 \mathrm{ml}$ of stroma suspension. Five tubes were incubated at $37^{\circ} \mathrm{C}$. At 0 time, 5, 10, 15 and 20 minutes, the reaction mixture was spun down at $28,000 \mathrm{G}$ and the supernatant was tested.

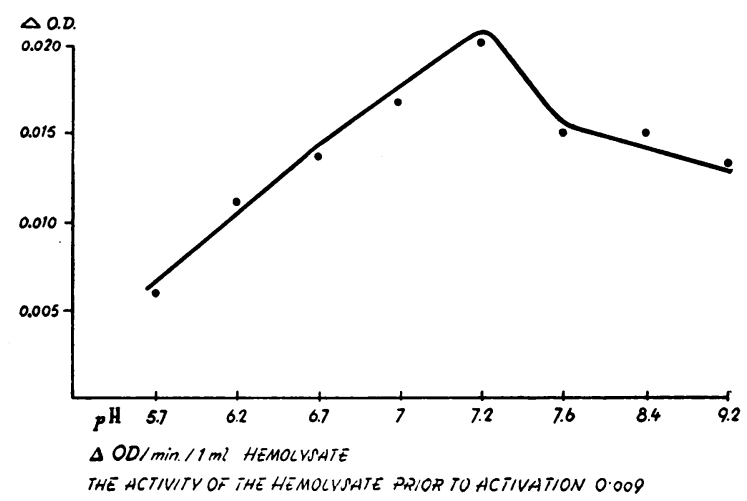

Fig. 2. The efFect of PH ON the aCtivation REACTION. The incubation mixture consisted of $1 \mathrm{ml}$ of "sensitive" hemolysate, $1 \mathrm{ml}$ of stroma suspension and 2 $\mathrm{ml}$ buffer, at the desired $\mathrm{pH}$, with 5 per cent succinic acid solution. The $\mathrm{pH}$ of the reaction mixture was tested and the obtained $\mathrm{pH}$ of the mixture is indicated in the figure. After incubation, the reaction mixture was centrifuged at $28,000 \mathrm{G}$ for 10 minutes and the supernatants were used for the assay.

represents the effect of mercury on both reactions. As can be seen from the figure, the activation reaction was found to be more sensitive to $\mathrm{Hg}$ than the G6PD activity per se. Fifty per cent inhibition of these two activities was obtained by $5 \times 10^{-7} \mathrm{M}$ $\mathrm{Hg}^{++}$and $5 \times 10^{-5} \mathrm{M} \mathrm{Hg}^{++}$, respectively. Similar results were obtained with $\mathrm{Ag}^{+}, \mathrm{Cu}^{++}$and parachloromercuribenzoate ( $\mathrm{p}-\mathrm{CMB}$, Table II).

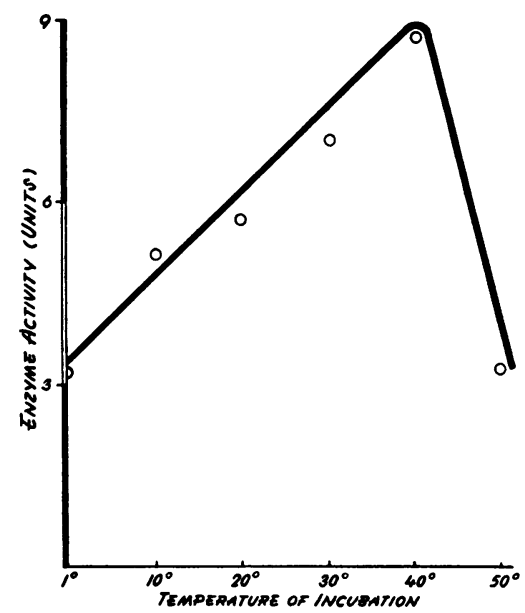

Fig. 3. The efFECt of temperature on the ACtivaTION REACTION. The incubation mixture consisted of 1 $\mathrm{ml}$ of "sensitive" hemolysate and $1 \mathrm{ml}$ of stroma suspension. Six tubes were incubated for 15 minutes at the indicated temperature. After the incubation the mixture was centrifuged at $28,000 \mathrm{G}$ for 10 minutes and the supernatant was tested. 


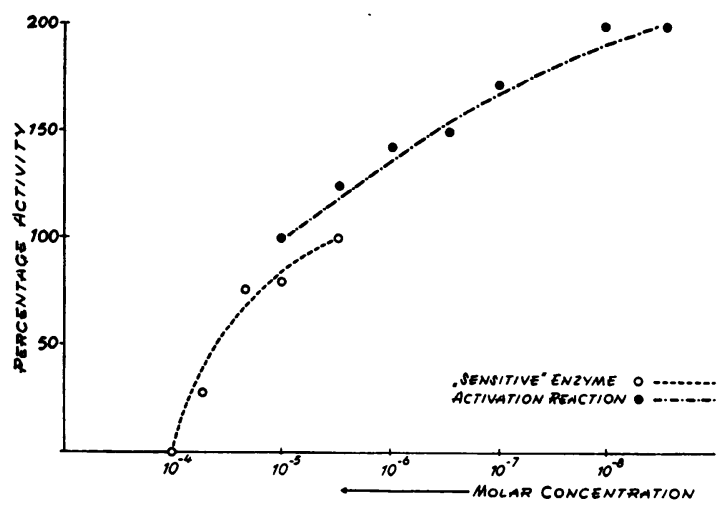

Fig. 4. The effect of $\mathrm{HG}^{++}$on G6PD ACtivity BeFORE AND AFTER ACTIVATION. The data are expressed as per cent activation. The maximal activity of G6PD prior to activation is referred to as 100 per cent. Since after activation the level of activity was twice the original level, it is referred to as 200 per cent. Samples of $1 \mathrm{ml}$ "sensitive" hemolysate $(\mathrm{O}--\mathrm{O})$ and activation reaction (---O), which consist of $1 \mathrm{ml}$ sensitive hemolysate and $1 \mathrm{ml}$ stroma suspension, were incubated with different concentrations of $\mathrm{Hg}^{++}$at $37^{\circ} \mathrm{C}$ for 30 minutes. After incubation the samples were spun down at 28,000 $\mathrm{G}$ for 10 minutes, and G6PD was assayed on the supernatant.

The action of the activator on partially purified enzyme was also tested; $0.5 \mathrm{ml}$ of stroma suspension was added to $0.5 \mathrm{ml}$ of partially purified enzyme solution which contained $0.045 \Delta$ A per minute per $0.5 \mathrm{ml}$. After 15 minutes, incubation the $\Delta$ A increased to $0.100 \Delta$ A per minute.

The enzyme obtained from three normal hemolysates could not be activated under the same experimental conditions.

The effect of various amounts of stroma on the activation of G6PD is given in Table III. As can be seen, maximal activation was obtained in 15 minutes by $1 \mathrm{ml}$ of normal stroma (30 $\mathrm{mg}$ dry weight) added to $1 \mathrm{ml}$ hemolysate. Smaller amounts of stroma did activate the sensitive he-
TABLE II

The effect of inhibitors on G6PD and the activation reaction

\begin{tabular}{lccc}
\hline \hline & \multicolumn{3}{c}{$\mathrm{I}_{60}$ values* } \\
\cline { 2 - 4 } & $\mathrm{Cu}$ & $\mathrm{Ag}$ & $\mathrm{p}$-CMB \\
\hline G6PD activity & $3 \times 10^{-4}$ & $1 \times 10^{-4}$ & $5 \times 10^{-5}$ \\
Activation reaction $\dagger$ & $7 \times 10^{-5}$ & $1 \times 10^{-5}$ & $5 \times 10^{-6}$ \\
\hline
\end{tabular}

* $I_{50}$ represents the molar concentration that causes 50 per cent inhibition of the reaction.

$\dagger$ The activation reaction which consisted of $1 \mathrm{ml}$ of hemolysate to $1 \mathrm{ml}$ of stromal suspension was incubated with the $\mathrm{Cu}^{++}, \mathrm{Ag}^{+}$, and $\mathrm{p}-\mathrm{CMB}$ in different concentrations for 15 minutes at $37^{\circ} \mathrm{C}$. After centrifugation for $10 \mathrm{~min}$ utes at 28,000 G, the G6PD was assayed in the supernatant.

molysate to the same level in a longer period of time. Larger amounts of stroma did not augment the G6PD activity in sensitive hemolysates more than $1 \mathrm{ml}$ of stroma. Furthermore, the ability of the stroma to activate G6PD remained practically unchanged after four successive activations, using the same stroma on different samples of sensitive hemolysates (Table IV).

The activator was found to be labile; it was destroyed when an acetone-dried powder was prepared from the stroma or by freezing and thawing the stroma. It was also completely destroyed by heating the stroma for 10 minutes at $80^{\circ} \mathrm{C}$, and partially destroyed at lower temperatures (Figure 5).

G6PD activity in red cell stroma. During our preliminary work on the activating capacity of normal red cell stroma, no G6PD or 6PGD could be demonstrated in it. Normal red cell stroma was incubated with water, saline or Tris buffer, $\mathrm{pH}$ 7.4, for up to 2 hours and no enzymatic activity could be shown in the supernatant. However, when the stroma was tested by the method of Motulsky, G6PD and 6PGD activities were de-

TABLE III

The effect of different amounts of stroma on G6PD activation (representative experiment)

\begin{tabular}{ccccccc}
\hline \hline & \multicolumn{5}{c}{ Time in minutes } \\
\cline { 5 - 7 } $\begin{array}{c}\text { Amt. of } \\
\text { stroma }\end{array}$ & $\begin{array}{c}\text { "Sensitive" } \\
\text { hemolysate }\end{array}$ & 0 & 15 & 30 & 45 & 60 \\
\hline$m l$ & $m l$ & & & $\Delta A / \min / 0.1 \mathrm{ml}$ & & \\
0.2 & 1 & 0.000 & 0.000 & 0.003 & 0.0064 & 0.010 \\
0.3 & 1 & 0.000 & 0.000 & 0.0044 & 0.010 & 0.010 \\
0.5 & 1 & 0.000 & 0.0024 & 0.008 & & 0.010 \\
1.0 & 1 & 0.000 & 0.010 & & & \\
2.0 & 1 & 0.000 & 0.010 & & & \\
\hline
\end{tabular}


TABLE IV

A comparison between the activating capacity of normal red cell stroma and its G6PD content *

\begin{tabular}{|c|c|c|}
\hline $\begin{array}{c}\text { Expt. } \\
\text { no. }\end{array}$ & Incubation mixture & G6PD activity $\dagger$ \\
\hline $\begin{array}{l}1 \\
2 \\
3\end{array}$ & $\begin{array}{l}\text { Hemolysate alone } \neq \\
\text { Stroma alone } \ddagger \\
\text { Stroma after } 5 \text { freezings and thawings }\end{array}$ & $\begin{array}{l}0.060 \\
0.000 \\
0.032\end{array}$ \\
\hline $\begin{array}{l}4 \\
5 \\
6 \\
7\end{array}$ & $\begin{array}{l}\text { Stroma + hemolysate } \\
\text { Stroma of Expt. } 4+\text { a second aliquot of hemolysate } \\
\text { Stroma of Expt. } 5 \text { + a third aliquot of hemolysate } \\
\text { Stroma of Expt. } 6+\text { a fourth aliquot of hemolysate }\end{array}$ & $\begin{array}{l}0.300 \\
0.280 \\
0.260 \\
0.200\end{array}$ \\
\hline $\begin{array}{l}8 \\
9\end{array}$ & $\begin{array}{l}\text { Stroma of Expt. } 7 \text { after } 5 \text { freezings and thawings } \\
\text { Stroma after } 4 \text { successive incubations with water followed } \\
\text { by } 5 \text { freezings and thawings (control of Expt. } 8 \text { ) }\end{array}$ & $\begin{array}{l}0.020 \\
0.030\end{array}$ \\
\hline
\end{tabular}

* All G6PD assays were performed on the supernatant after 10 minutes' centrifugation at $28,000 \mathrm{G}$.

† In $\Delta \mathrm{A}$ per minute per $1 \mathrm{ml}$ stroma or hemolysate.

$\ddagger$ In all the experiments "sensitive" hemolysate and/or normal stroma were used; $1 \mathrm{ml}$ of each was incubated for 15 minutes at $37^{\circ} \mathrm{C}$ prior to G6PD assay. Aliquots of the same stroma suspension and the same hemolysate were used in all the experiments.

tected in normal red cell stroma and only 6PGD activity in sensitive stroma. In normal stroma the change in color from blue to red appeared after less than 2 hours. In sensitive stroma no discoloration was observed after 12 hours when glucose-6-phosphate was used. When 6-phosphogluconate was used, the change in color appeared after less than 2 hours, as in normal stroma. In view of this finding, the possibility arose that the effect of normal stroma on sensitive hemolysate could be the result of G6PD elution from the stroma rather than a reaction from the activation.

The following experiments were performed to elucidate this issue. One $\mathrm{ml}$ stroma suspended in water was frozen up to 10 times and the supernatant was tested for G6PD and 6PGD activities; the mean of five experiments is presented in Table

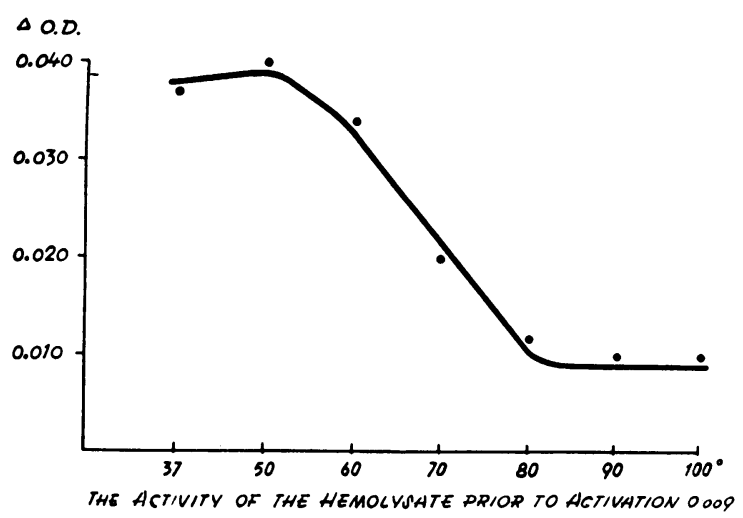

FIG. 5. THE EFFECT OF HEATING ON ERYTHROCYTE STROMA PRIOR TO THE ACTIVATION REACTION.
V. When the amount of stroma was doubled or tripled, the amount of enzyme released upon freezing also doubled or tripled. In Table IV we compare the activating capacity of $1 \mathrm{ml}$ of stroma to its G6PD content. As can be seen from this table, the amount of enzyme released from normal stroma was found to be much smaller than the increase of G6PD activity in a sensitive hemolysate incubated with normal stroma. The same stroma on four consecutive activations increased the G6PD activity of sensitive hemolysate about 30 times more than the amount of enzyme that could have been released from this amount of stroma by freezing and thawing. Furthermore, when the same stroma was frozen and thawed, the amount of G6PD released was not much lower than the amount of enzyme that was present in the stroma before activation (Table IV). In addition, G6PD could not be extracted from stroma suspended in $1 \mathrm{M}$ or $2 \mathrm{M} \mathrm{NaCl}$ solution. These results prove that the increase of G6PD activity in sensitive he-

TABLE V

G6PD and 6PGD activities in red cell stroma *

\begin{tabular}{cccc}
\hline Material & Amount & G6PD & 6PGD \\
\hline & $m l$ & $\Delta A / m i n / m l$ & stroma \\
Normal stroma & 1 & 0.040 & 0.030 \\
"Sensitive" stroma & 1 & 0.008 & 0.032
\end{tabular}

* One $\mathrm{ml}$ of the respective stromas, containing about 30 mg dry weight, was frozen and thawed 10 times. The sample was centrifuged at $28,000 \mathrm{G}$ for 10 minutes and the supernatant was used for enzymatic assay. 
molysates upon the addition of normal stroma was indeed an activation reaction and not an elution of enzyme from stroma.

As far as the bound G6PD and 6PGD are concerned, the question arose of whether these are the same enzyme as that in the hemolysate. The $\mathrm{pH}$ optimum and temperature lability were found to be the same for the bound and soluble G6PD. Since these data were obtained on crude preparations, no final conclusions can yet be drawn.

\section{DISCUSSION}

The main defect in the erythrocytes of individuals "sensitive" to primaquine and other drugs as well as to fava beans was considered to be the low glucose-6-phosphate dehydrogenase activity $(1,2)$. This enzymatic defect was found in Negroes, non-Ashkenazic Jews, Sardinians, Sicilians, Chinese and others (10-12). This defect is transmitted as a sex-linked incompletely dominant trait with variable expressivity in the heterozygous female $(13,14)$. In "sensitive" Jews and Italians the enzymatic defect was found in other tissues also, while in Negroes the defect was found solely in the erythrocytes $(8,15-18)$.

Recently we observed that normal red cell stroma was capable of partial restoration of the enzymatic activity of sensitive hemolysates (5); this finding could suggest that the enzymatic deficiency in those individuals is of only secondary nature, while the primary defect is possibly in the stroma. This suggestion is strengthened by the fact that several authors were unable to show any qualitative difference between the G6PD of normal and sensitive erythrocytes $(3,4)$.

Since we demonstrated that there are stromabound G6PD and 6PGD, the major problem was to exclude the possibility that the activation effect was not the result of elution of the enzymes from the stroma. The following results confirm our earlier observations (5).

a) The augmentation in the G6PD activity was observed only when normal stroma was incubated with a sensitive hemolysate. Normal stroma had no effect on a normal hemolysate; in fact, it frequently decreased its activity. b) G6PD could not be eluted from stroma incubated at $37^{\circ}$ with water, saline, or Tris buffer. c) The activating capacity of stroma did not depend upon the amount of stroma. Small amounts of stroma activated as well as large amounts, the difference being only in the rate of the reaction (Table III). d) The activating capacity of normal red cell stroma was found to be out of proportion to its G6PD content, as shown in Table VI. $e$ ) The activating capacity of frozen stroma was destroyed, while such stroma showed G6PD activity by the method of Motulsky.

These results prove that the effect obtained by normal red cell stroma on sensitive hemolysates is the result of G6PD activation. The behavior of the activation reaction-namely its temperature, $\mathrm{pH}$ and time-dependence as well as the capacity of the same stroma to activate successive samples of sensitive hemolysate and a sensitive partially purified G6PD-suggested its being an enzymeenzyme activation similar to the activation of chemotrypsinogen by trypsin or of phosphorylase by phosphorylase-activating-enzyme $(19,20)$. However, from the data mentioned it is not yet possible to suggest a definite mechanism of the G6PD activation.

The possibility that sensitive stroma possessed an inhibitor of the G6PD activator was excluded, since sensitive stroma did not inhibit the activating capacity of normal red cell stroma on sensitive hemolysates.

The effect of heavy metal ions and $\mathrm{p}-\mathrm{CMB}$ on this reaction suggests that sulfhydryl groups may be important in this reaction. Only after a highly purified G6PD is obtained, will it be possible to learn more about the specificity of the activator. Difficulties arose when we tried to purify the activator. Since it was a labile substance, it was destroyed by freezing and thawing of the stroma, by heating the stroma to $80^{\circ} \mathrm{C}$, and when an acetone powder of stroma was prepared.

Our present hypothesis is that G6PD is synthesized in an inactive form in both normal and sensitive subjects. In the normal subject the enzyme is activated by an erythrocyte stroma factor. Since such an activator was found to be absent in sensitive red cells, lack of it may be responsible for the apparently low or deficient G6PD activity. In the normal erythrocytes the activator probably activated the G6PD to a maximal level in vivo, since the addition of normal stroma to normal hemolysate did not increase the enzymatic activity. This hypothesis will not change the genetic aspects of this abnormality, the only implication being that the primary genetic lesion affects the 
G6PD activator, rather than the enzyme per se. Using this hypothesis, heterozygous females with varying levels of this enzyme are being investigated.

\section{SUMMARY}

1. A factor capable of activating glucose-6-phosphate dehydrogenase of "sensitive" erythrocytes was found in normal red cell stroma. This activation reaction was found to be dependent upon time, temperature and $\mathrm{pH}$. The inhibitory affects of $\mathrm{Ag}^{+}, \mathrm{Hg}^{++}, \mathrm{Cu}^{++}$and parachloromercuribenzoate were studied. The kinetics of the activation reaction suggest that it is enzymatic.

2. This activator was destroyed by freezing and thawing, heating, and cold acetone treatment.

3 . Small amounts of tightly bound glucose-6phosphate and 6-phosphogluconic dehydrogenase were detected in red cell stroma.

4. The data prove that the glucose-6-phosphate dehydrogenase activation is not the result of elution of the enzyme from normal red cell stroma.

\section{ACKNOWLEDGMENTS}

We thank Professor B. Shapiro, Dept. of Biochemistry, Hadassah Medical School, Jerusalem, and Professor N. O. Kaplan, Dept. of Biochemistry, Brandeis University, USA, for discussion of the results and valuable suggestions; and Dr. S. Rimon, University of Tel-Aviv, for helpful criticism.

\section{REFERENCES}

1. Carson, P. E., Flanagen, C. L., Ickes, C. E., and Alving, A. S. Enzymatic deficiency in primaquinesensitive erythrocytes. Science 1956, 124, 484.

2. Szeinberg, A., Sheba, C., and Adam, A. Enzymatic abnormality in erythrocytes of a population sensitive to vicia faba or haemolytic anaemia induced by drugs. Nature (Lond.) 1958, 181, 1256.

3. Kirkman, H. N. Characteristics of glucose-6-phosphate dehydrogenase from normal and primaquinesensitive erythrocytes. Nature (Lond.) 1959, 184, 1291.

4. Marks, P. A., and Szeinberg, A. Stabilization and inactivation of glucose-6-phosphate dehydrogenase of normal and mutant subjects. Fed. Proc. 1960, 19, 193.

5. Rimon, A., Askenazi, I., Ramot, B., and Sheba, C. Activation of glucose-6-phosphate dehydrogenase of enzyme deficient subjects. I. Activation by stroma of normal erythrocytes. Biochem. biophys. Res. Com. 1960, 2, 138.

6. Kornberg, A., and Horecker, B. L. Glucose-6-phosphate dehydrogenase in Methods in Enzymology,
S. P. Colowick and N. O. Kaplan, Eds. New York, Academic Press, 1955, vol. 1, p. 323.

7. Horecker, B. L., and Smyrniotis, P. Z. Phosphogluconic acid dehydrogenase from yeast. J. biol. Chem. 1951, 193, 371.

8. Ramot, B., Szeinberg, A., Adam, A., Sheba, C., and Gafni, D. A study of subjects with erythrocyte glucose-6-phosphate dehydrogenase deficiency: Investigation of platelet enzymes. J. clin. Invest. 1959, 38, 1659.

9. Motulsky, A. G., and Campbell, J. M. A screening test for glucose-6-phosphate dehydrogenase deficiency of the red cell suitable genetic surveys. Possible relationship of the enzyme defect to malaria. Blood. In press.

10. Beutler, E., Dern, R. J., Flanagen, C. L., and Alving, A. S. The hemolytic effect of primaquine. VII. Biochemical studies of drug-sensitive erythrocytes. J. Lab. clin. Med. 1955, 45, 286.

11. Szeinberg, A., Sheba, C., Hirshorn, N., and Bodonyi, E. Studies on erythrocytes in cases with past history of favism and drug-induced acute hemolytic anemia. Blood 1957, 12, 603.

12. Beutler, E. The hemolytic effect of primaquine and related compounds: A review. Blood 1959, 14, 103.

13. Childs, B., Zinkham, W., Browne, E. A., Kimbro, E. L., and Torbert, J. V. A genetic study of a defect in glutathione metabolism of the erythrocyte. Bull. Johns Hopk. Hosp. 1958, 102, 21.

14. Szeinberg, A., Sheba, C., and Adam, A. Selective occurrence of glutathione instability in red blood corpuscles of the various Jewish tribes. Blood 1958, 13, 1043.

15. Ramot, B., Fisher, S., Szeinberg, A., Adam, A., Sheba, C., and Gafni, D. A study of subjects with erythrocyte glucose-6-phosphate dehydrogenase deficiency. II. Investigation of leukocyte enzymes. J. clin. Invest. 1959, 38, 2234.

16. Marks, P. A., Gross, R. T., and Hurwitz, R. E. Gene action in erythrocyte deficiency of glucose-6-phosphate dehydrogenase: Tissue enzyme-levels. Nature (Lond.) 1959, 183, 1266.

17. Marks, P. A., and Gross, R. T. Erythrocyte glucose-6-phosphate dehydrogenase deficiency: Evidence of differences between Negroes and Caucasians with respect to this genetically determined trait. J. clin. Invest. 1959, 38, 2253.

18. Ramot, B., Sheba, C., Adam, A., Ashkenasi, I. Erythrocyte glucose-6-phosphate-dehydrogenase deficient subjects: Enzyme-level in saliva. Nature (Lond.) 1960, 185, 931.

19. Sumner, J. B., Ed. The Enzymes; Chemistry and Mechanism of Action. New York, Academic Press, 1950-52, vol. 1, part 2, p. 849.

20. Rall, T. W., Sutherland, E. W., and Wosilait, W. D. The relationship of epinephrine and glucagon to liver phosphorylase. III. Reactivation of liver phosphorylase in slices and in extracts. J. biol. Chem. 1956, 218, 483. 